\title{
SIMULTANEOUS ESTIMATION OF AZILSARTAN AND CILNIDIPINE IN BULK BY RP-HPLC AND ASSESSMENT OF ITS APPLICABILITY IN MARKETED TABLET DOSAGE FORM
}

\author{
SWATI M. ANDHALEa, ANNA PRATIMA G. NIKALJE ${ }^{\text {b* }}$
}

aY. B. Chavan College of Pharmacy, Rauza Bag, Aurangabad 431001, MS, India, bWilson College, Chowpatty Seaface Road, Mumbai 400007, MS, India

*Email: annapratimanikalje@gmail.com

Received: 27 May 2021, Revised and Accepted: 25 Oct 2021

\section{ABSTRACT}

Objective: This study aims to build up the RP-HPLC process for Azilsartan and Cilnidipine and authenticate the RP-HPLC process according to ICH validation code Q2R1.

Methods: System suitability testing was performed to discover the qualifying criterion of the method by injecting the identical standard solution of Azilsartan $40 \mu \mathrm{g} / \mathrm{ml}$ and Cilnidipine $10 \mu \mathrm{g} / \mathrm{ml}$ in mixture/combination in subsequent optimized chromatographic conditions and the chromatogram was recorded. Moreover, the planned method was validated as per ICH guideline Q2R1 for the following parameters: linearity and range, precision, accuracy, robustness, and determined \% recovery.

Results: The outcomes of \%RSD for retention time and peak area were found to be 0.65 and 1.32 for Azilsartan and 0.85 and 1.90 for Cilnidipine. The correlation coefficient, y-intercept, slope of the regression line were 0.9996,-1127.1, 3313.9, and 0.9993, 1460.2, 2876.4 for Azilsartan and Cilnidipine, respectively. Moreover, the range of this method was observed to be $40-240 \mu \mathrm{g} / \mathrm{ml}$ and $10-60 \mu \mathrm{g} / \mathrm{ml}$ for Azilsartan and Cilnidipine, standard concentrations respectively. The \% RSD achieved for precision (repeatability) was observed in the range of 1.57 to 2.43 for Azilsartan and 0.70 to 1.88 for Cilnidipine. The \% accuracy was found in the range of 96.96 to $101.92 \% \mathrm{w} / \mathrm{w}$ for Azilsartan and 99.19 to $101.96 \% \mathrm{w} / \mathrm{w}$ for Cilnidipine. The percent recovery values achieved for Azilsartan were in the range of 99.87 to $106.39 \% \mathrm{w} / \mathrm{w}$ and for Cilnidipine in the range of 94.51 to $105.96 \% \mathrm{w} / \mathrm{w}$.

Conclusion: The author concludes that the simultaneous estimation of Azilsartan and Cilnidipine with predefined objectives was successfully achieved. Moreover, the method was found to be steadfast for the quantification of Azilsartan and Cilnidipine in marketed tablet dosage forms.

Keywords: Azilsartan, Cilnidipine, RP-HPLC, Linearity and range, Precision, \%Accuracy, Robustness, Limit of detection, Limit of quantitation

(C) 2022 The Authors. Published by Innovare Academic Sciences Pvt Ltd. This is an open access article under the CC BY license (https://creativecommons.org/licenses/by/4.0/) DOI: https://dx.doi.org/10.22159/ijap.2022v14i1.42208. Journal homepage: https://innovareacademics.in/journals/index.php/ijap

\section{INTRODUCTION}

RP-HPLC is a widely used analytical technique for separating components from the mixture and their quantification [1]. It is a widely accepted technique and used in various fields to analyze and quantify different chemical entities due to its speed and column stability [2]. Chemically Azilsartan Medoxomil is Chemically Azilsartan is (5-methyl-2-oxo-2H-1,3-dioxol-4-yl)methyl 2-ethoxy-1(\{4-[2-(5-oxo-4,5-dihydro-1,2,4-oxadiazol-3-yl)phenyl]phenyl\} methyl)-1H-1,3-benzodiazole-7-carboxylate (fig. 1) [3]. Azilsartan Medoxomil is an angiotensin II receptor antagonist used in the treatment of hypertension. It inhibits the vasoconstrictive effects of angiotensin II (a peptide) in the body [4]. Also, it is responsible for aldosterone secretion and thereby regulates the fluid balance in the body. This further helps in the control of blood pressure. It is available in doses of $40 \mathrm{mg}$ and $20 \mathrm{mg}$ for the management of hypertension $[5,6]$.

Cilnidipine is a novel analogue in the category of calcium channel antagonist [7]. Chemically it is named as 1,4-dihydro-2,6-dimethyl4-(3-nitrophenyl)-3,5-pyridine carboxylic acid 2-methoxyethyl(2E)3-phenyl-propenyl ester (fig. 1) [8]. It acts on long-acting $\mathrm{Ca}+2$ channels, thereby restricting calcium ions' entry inside the small blood vessels. Blockade of entry of $\mathrm{Ca}+2$ leads to inhibition of vasoconstriction cascade, eventually resulting in vasodilatation. It helps to decrease peripheral resistance and, therefore, blood pressure $[9,10]$. It also acts on N-type calcium channels present at the neuronal terminals [11]. It reduces the outflow of norepinephrine from the neuronal terminal and aids in reducing stress and hence blood pressure [12].

Extensive literature research revealed some analytical methods for the estimation of Azilsartan medoxomil by RP-HPLC alone [13, 14] Further, Sreenivasulu J et al. reported the estimation of related compounds in Azilsartan medoxomil using LC-MS [15]. Chandana et al. recently reported stability-indicating the RP-HPLC method for the estimation of Azilsartan medoxomil and its related substances. In addition, literature also exposed simultaneous estimation of Azilsratan medoxomil with chlorthalidone [16, 17]. Similarly, the RP-HPLC methods were seen in the literature for simultaneous estimation of Cilnidipine with Chlorthalidone $[18,19]$ and Olmesartan [20]. Also, the literature survey does not explore any method for simultaneous estimation of Azilsartan medoxomil and cilnidipine in the mixture as API and dosage form, although the combined dosage form is available in the market. Hence the presented method is novel.

Therefore, there was an unmet need to explore the simultaneous estimation of Azilsartan medoxomil and Cilnidipine as API and assessment of its applicability in marketed tablet dosage form. Hence this original article is an endeavor to develop and validate (as per ICH guidelines) an accurate, precise, sensitive, robust RP-HPLC method for simultaneous estimation of Azilsartan medoxomil and Cilnidipine.

\section{MATERIALS AND METHODS}

\section{Chemicals and reagents}

Potassium dihydrogen phosphate, tri-ethylamine, and orthophosphoric acid were purchased from Thermo Fisher Scientific India. Azilsartan Medoxomil was purchased from a local vendor. Cilnidipine was procured as a gift sample from Emcure pharmaceuticals ltd. Pune, Maharashtra. All the chemicals and reagents used in the present study were HPLC grade.

\section{Instruments and evaluation conditions}

The separation and quantification of Azilsartan Medoxomil and Cilnidipine were achieved employing Shimadzu LC-20AT Prominence HPLC system, equipped with SPD 20A detector. The 
separation was performed using Hypersil ODS $\mathrm{C}_{18}(250 \mathrm{~mm} \times 4.6$ $\mathrm{mm}$ ), $5 \mu \mathrm{m}$ id column with ambient temperature. The mobile phase seen suitable for the study was Acetonitrile and potassium dihydrogen phosphate buffer of $\mathrm{pH} 3.0$ in the proportion of 80:20\% $\mathrm{v} / \mathrm{v}$. The flow rate was maintained at $1.2 \mathrm{ml} / \mathrm{min}$. The mobile phase was filtered through a $0.45 \mu$ membrane filter and also degassed before use. The injection volume was $10 \mu \mathrm{l}$ and the detector was set at $250 \mathrm{~nm}$. The method run time was $12 \mathrm{~min}$.
Table 1: Optimized chromatographic conditions

\begin{tabular}{ll}
\hline \multicolumn{2}{l}{ Chromatographic conditions } \\
\hline Column & C18 $(250 \mathrm{~mm} \times 4.6 \mathrm{~mm}), 5 \mu \mathrm{m}$ id \\
Mobile phase & $\begin{array}{l}\text { Acetonitrile 80: Potassium dihydrogen } \\
\text { phosphate buffer (Phosphate buffer) } 20 \\
\text { (pH 3.0) v/v }\end{array}$ \\
& $250 \mathrm{~nm}$ (Isobestic Point) \\
Detection wavelength & $1.2 \mathrm{ml} / \mathrm{min}$ \\
Flow rate & Ambient \\
Temperature & $10 \mu \mathrm{l}$ \\
Sample size & $12 \mathrm{~min}$ \\
Run Time & \\
\hline
\end{tabular}

\section{Linearity}

Aliquots of 1.0, 2.0, 3.0, 4.0, 5.0, and $6.0 \mathrm{ml}$ standard stock solution (Azilsartan Medoxomil $400 \mu \mathrm{g} / \mathrm{ml}$ and Cilnidipine $100 \mu \mathrm{g} / \mathrm{ml}$ ) were pulled out and taken into a $10 \mathrm{ml}$ volumetric flask. The volume of the afterward was made up to $10 \mathrm{ml}$ with mobile (acetonitrile 80: $\mathrm{KH}_{2} \mathrm{PO}_{4}$ buffer $20, \mathrm{pH} 3.0$ ) to find the following solution of 40,80 , $120,160,200,240 \mu \mathrm{g} / \mathrm{ml}$ in that order for Azilsartan Medoxomil and $10,20,30,40,50$ and $60 \mu \mathrm{g} / \mathrm{ml}$ for Cilnidipine. All of these standard working solutions of Azilsartan Medoxomil and Cilnidipine (in the mixture) were injected as a mixture in triplicate to the optimized chromatographic parameters and mean peak area was determined [29]. A calibration curve was arranged among the concentration of standard solutions of Azilsartan Medoxomil and Cilnidipine. Mean peak area consequential out of chromatographic measurement with each standard concentration. From the calibration curve equation of the line, correlation coefficient and intercept were calculated. The general equation of a straight line is as mentioned underneath.

\section{Fig. 1: Structure of drugs}

\section{Formulation used}

Myotan 40 tablets (Synochem Pharmaceutical Ltd), with the strength of Azilsartan Medoxomil $40 \mathrm{mg}$ and Cilnidipine $10 \mathrm{mg}$ were purchased from the local medical store at Aurangabad. This formulation was utilized to study the relevance of the present method for estimation of Azilsartan Medoxomil and Cilnidipine in the marketed tablet dosage form.

\section{Preparation of standard stock solution of azilsartan medoxomil and cilnidipine}

Weighed accurately $40 \mathrm{mg}$ of Azilsartan Medoxomil and $10 \mathrm{mg}$ Cilnidipine and transferred to identical $100 \mathrm{ml}$ volumetric flask containing a mixture of acetonitrile: phosphate buffer $(\mathrm{pH} 3.0)$ (80:20), the mobile phase. The volume was made up to the mark with the help of the mobile phase. The consequential standard stock solutions of Azilsartan Medoxomil $(400 \mu \mathrm{g} / \mathrm{ml})$ and Cilnidipine $(100 \mu \mathrm{g} / \mathrm{ml})$ were filtered through a $0.45 \mu$ membrane filter and ultrasonicated for 3 cycles each of $10 \mathrm{~min}$. This standard stock was employed for preparing various concentration solutions required in the different validation parameters.

\section{Preparation of working solution}

Aliquot $1.0 \mathrm{ml}$ stock solution was taken from the above standard stock solution of Azilsartan Medoxomil and Cilnidipine. The aliquot was transferred to an identical $10 \mathrm{ml}$ volumetric flask. It was then diluted up to $10 \mathrm{ml}$ using mobile phase to attain resultant solution consisting of $40 \mu \mathrm{g} / \mathrm{ml}$ of Azilsartan Medoxomil and $10 \mu \mathrm{g} / \mathrm{ml}$ Cilnidipine. This outfitted solution was degassed by an ultrasonicator for $10 \mathrm{~min}$.

\section{Procedures}

\section{System suitability testing}

This test was performed using $40 \mu \mathrm{g} / \mathrm{ml}$ and $10 \mu \mathrm{g} / \mathrm{ml}$ Azilsartan Medoxomil and Cilnidipine, respectively. The study was conducted using six repeated measurements in the optimized chromatographic conditions, as illustrated in table 1.

$$
y=m x+c
$$

Where, $\mathrm{Y}=$ Peak area; $\mathrm{m}=$ slope; $\mathrm{X}=$ measured concentration; $\mathrm{c}=$ intercept.

\section{Precision}

The precision of the method was studied by assessment and repeatability and intermediate precision. Across the range, the three

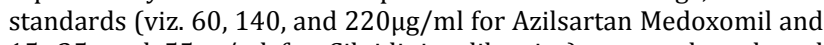
15,35 , and $55 \mu \mathrm{g} / \mathrm{ml}$ for Cilnidipine likewise) were selected, and three replicates of the same were injected into the optimized chromatographic conditions to determine peak area. Appropriate statistical analysis was performed to calculate statistical parameters [30]. Repeatability was studied by measurements of three standards and its three replicates in a day. However, the intermediate precision was studied on different days.

\section{$\%$ recovery (\% accuracy) by standard addition method}

\section{Preparation of standard concentrations of azilsartan medoxomil and cilnidipine}

The $40 \mu \mathrm{g} / \mathrm{ml}$ and $10 \mu \mathrm{g} / \mathrm{ml}$ standard solutions of Azilsartan Medoxomil and Cilnidipine were prepared as procedure mentioned above in triplicate and kept in three different volumetric flasks.

\section{Preparation of sample concentrations of azilsartan medoxomil and cilnidipine}

Twenty tablets of the combined dosage form of Azilsartan Medoxomil and Cilnidipine (Myotan CN 40/10, labeled claim Azilsartan Medoxomil $40 \mathrm{mg}$, Cilnidipine $10 \mathrm{mg}$ J B Chemicals and Pharmaceutical Ltd.) were weighed; average weight $(0.1844 \mathrm{gm})$ was determined and powdered. Powder equivalent to $40 \mathrm{mg}$ of Azilsartan Medoxomil, 0.1844g (10 mg of Cilnidipine) was weighed and pulled out to $100 \mathrm{ml}$ of mobile phase to achieve the sample stock solution of Azilsartan Medoxomil $400 \mu \mathrm{g} / \mathrm{ml}(100$ $\mu \mathrm{g} / \mathrm{ml}$ for Cilnidipine). The resulting sample solution was filtered through a $0.45 \mu$ membrane filter and degassed using ultrasonicated for 3 cycles each of $10 \mathrm{~min}$. From the sample stock solution, an aliquot of $1.0 \mathrm{ml}$ was taken with a micropipette, transferred to a $10 \mathrm{ml}$ volumetric flask, and diluted up to the mark with mobile phase to acquire a consequential solution of $40 \mu \mathrm{g} / \mathrm{ml}$ for Azilsartan Medoxomil $(10 \mu \mathrm{g} / \mathrm{ml}$ for Cilnidipine). Likewise, 
aliquots of 0.8 and $1.2 \mathrm{ml}$ were pulled out from the sample stock solution $(400 \mu \mathrm{g} / \mathrm{ml}$ and $100 \mu \mathrm{g} / \mathrm{ml})$ to acquire the operational sample solutions of 32 and $48 \mu \mathrm{g} / \mathrm{ml}$ ( 8 and $12 \mu \mathrm{g} / \mathrm{ml}$ for Cilnidipine, respectively). The three sample solutions of combined dosage form viz. 32, 40 , and $48 \mu \mathrm{g} / \mathrm{ml}$ and 8,10 , and $12 \mu \mathrm{g} / \mathrm{ml}$ (Azilsartan Medoxomil and Cilnidipine, respectively) were labeled as three levels of percent recovery testing viz. 80, 100, and $120 \%$ in that order.

\section{Preparation of test solution for \% recovery}

$40 \mu \mathrm{g} / \mathrm{ml}$ and $10 \mu \mathrm{g} / \mathrm{ml}$ standard solution of a mixture of Azilsartan Medoxomil and Cilnidipine was spiked into every sample solution of combined dosage form viz. 32,40 and $48 \mu \mathrm{g} / \mathrm{ml}$ and 8,10 and $12 \mu \mathrm{g} / \mathrm{ml}$ to attain test solutions at $80 \%, 100 \%$ and $120 \%$ levels correspondingly. Each of these 3 percent recovery levels was injected in triplicate in optimized chromatographic conditions of the projected method. The mean peak area for each percent recovery level was determined. The recovery was calculated from the following formula [31].

$\%$ Recovery $=\frac{\text { sample peak area }}{\text { standard peak area }} \times \frac{\text { standard concentration }}{\text { sample concentration }} \times 100$

\section{Robustness}

The robustness of the proposed simultaneous method of Azilsartan Medoxomil and Cilnidipine was studied by deliberate redecoration in method parameters $[24,25]$. In the present experimentation, the method parameters viz. detector wavelength in ' $\mathrm{nm}$ ', the flow rate of the mobile phase in ' $\mathrm{mL} / \mathrm{min}$ ', and organic concentration of the mobile phase were altered as per table 2 . The standard solution with concentrations of Azilsartan Medoxomil $(40 \mu \mathrm{g} / \mathrm{ml})$ and Cilnidipine $(10 \mu \mathrm{g} / \mathrm{ml})$ was selected for this examination. It was maintained stable throughout the robustness study till all planned variations were effected. The measurements were made in triplicate.

Table 2: Experimental design of robustness experiment

\begin{tabular}{lll}
\hline Method parameter & Standard & Variation 1 \\
\hline Wavelength in 'nm' & 250 & 251 \\
Flow rate of mobile phase in $\mathrm{ml} / \mathrm{min}( \pm 0.1 \mathrm{ml} / \mathrm{min})$ & 1.2 & 1.3 \\
Organic conc. of Mobile phase $( \pm 2 \%)$ & 80 & 1.1 \\
\hline
\end{tabular}

\section{LOD and LOQ determination}

LOD and LOQ were calculated Based on the standard deviation of the response and the slope using the following formulae.

$$
\begin{aligned}
& \text { LOD }=\frac{3.3 \times \sigma}{\text { Slope }} \\
& \text { LOQ }=\frac{10 \times \sigma}{\text { Slope }}
\end{aligned}
$$

Where $\sigma=$ the standard deviation of the responses.
The slope was estimated from the calibration curve. The standard deviation of the responses was calculated by determining the standard deviation of the y-intercept of the regression line. The latter was used as a standard deviation [26, 27].

\section{RESULTS}

System suitability testing (SST)

This was performed by six repeated measurements of the standard solutions of Azilsartan Medoxomil and Cilnidipine $(40 \mu \mathrm{g} / \mathrm{ml}$ and 10 $\mu \mathrm{g} / \mathrm{ml}$ ). The results acquired were as tabulated in table 3 .

\begin{tabular}{|c|c|c|c|c|}
\hline \multirow[t]{2}{*}{ S. No. } & \multicolumn{2}{|l|}{ Peak area } & \multicolumn{2}{|l|}{ RT in 'min.' } \\
\hline & Azilsartan medoxomil & Cilnidipine & Azilsartan medoxomil & Cilnidipine \\
\hline 1 & 50992 & 4.03 & 31847 & 7.21 \\
\hline 2 & 52431 & 4.01 & 33281 & 7.16 \\
\hline 3 & 51426 & 3.99 & 32231 & 7.12 \\
\hline 4 & 50987 & 3.98 & 32011 & 7.11 \\
\hline 5 & 52297 & 3.97 & 33069 & 7.06 \\
\hline 6 & 52310 & 3.96 & 33021 & 7.05 \\
\hline Avg. area $(n=6)$ & 51740.50 & 3.99 & 32576.67 & 7.12 \\
\hline SD & 683.77 & 0.03 & 617.70 & 0.06 \\
\hline$\%$ RSD & 1.32 & 0.65 & 1.90 & 0.85 \\
\hline
\end{tabular}

Table 3: Outcomes of the system suitability testing

$\mathrm{n}=6$; SD: Standard deviation of the responses; \%RSD: \% relative standard deviation, the representative chromatogram observed in system suitability testing was as depicted in fig. 2 .

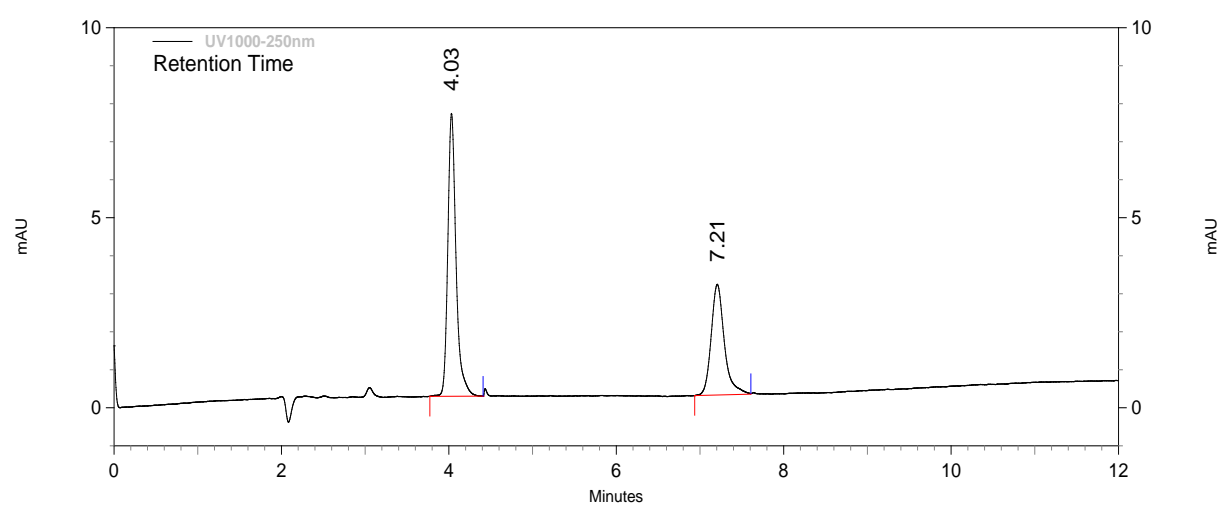

Fig. 2: The chromatogram observed in SST of azilsartan medoxomil and cilnidipine 


\section{Linearity}

The linearity of the method was seen in the range of $40-240 \mu \mathrm{g} / \mathrm{ml}$ and $10-60 \mu \mathrm{g} / \mathrm{ml}$ for Azilsartan Medoxomil and Cilnidipine (AZL and CIL), respectively. The study was performed with three replicates measurements of each standard solution of AZL as well as CIL. The average area is explored in table 4. The calibration curve was constructed against the average peak area and the standard concentrations of AZL and CIL. The calibration curves observed were as exposed in fig. $3 \mathrm{a}$ and $3 \mathrm{~b}$. The equation of regression line, slope, and y-intercept were estimated and shown in fig. 3a and $3 \mathrm{~b}$.

\section{Precision}

The precision of the presented method was studied by measuring three standards and three replicates of each covering total of nine determinations. Repeatability was assessed by measuring three standards and three replicates on the same day. However, intermediate precision (ruggedness) was studied on three different days. The results observed are shown in table 5 for repeatability and table 6,7 , etc. for an intermediate precision. The statistical parameters like standard deviation and relative standard deviation were also calculated and shown in Tables 5, 6, and 7.

Table 4: Outcomes of the linearity experiment of azilsartan medoxomil and cilnidipine

\begin{tabular}{|c|c|c|c|c|c|c|c|}
\hline \multicolumn{2}{|c|}{ Conc. $(\mu \mathrm{g} / \mathrm{ml})$} & \multicolumn{2}{|c|}{ Avg. peak area $(n=3)$} & \multicolumn{2}{|l|}{ SD } & \multicolumn{2}{|c|}{ \%RSD } \\
\hline AZL & CIL & AZL & CIL & AZL & CIL & AZL & CIL \\
\hline 40 & 10 & 47217 & 29975 & 1122.02 & 366.85 & 2.38 & 1.22 \\
\hline 80 & 20 & 93712 & 57877 & 735.02 & 316.39 & 0.78 & 0.55 \\
\hline 120 & 30 & 138730 & 88724 & 2232.68 & 708.53 & 1.61 & 0.80 \\
\hline 160 & 40 & 184721 & 116918 & 1108.06 & 554.25 & 0.60 & 0.47 \\
\hline 200 & 50 & 231071 & 147240 & 578.10 & 718.36 & 0.25 & 0.49 \\
\hline 240 & 60 & 271189 & 172064 & 724.85 & 1705.31 & 0.27 & 0.99 \\
\hline
\end{tabular}

$\mathrm{n}=3$ : results three repeated injections; SD: standard deviation; \%RSD: \% relative standard deviation; AZL: Azilsartan Medoxomil; CIL: Cilnidipine

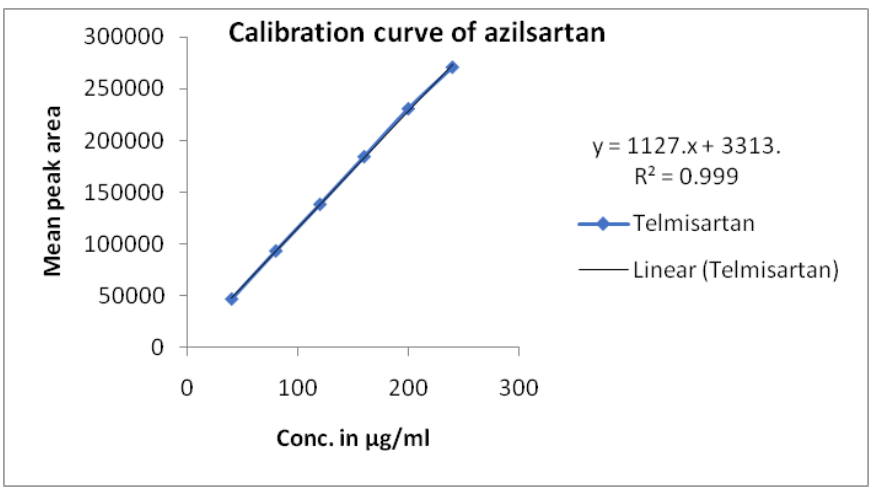

Fig. 3a: Calibration curve of azilsartan medoxomil

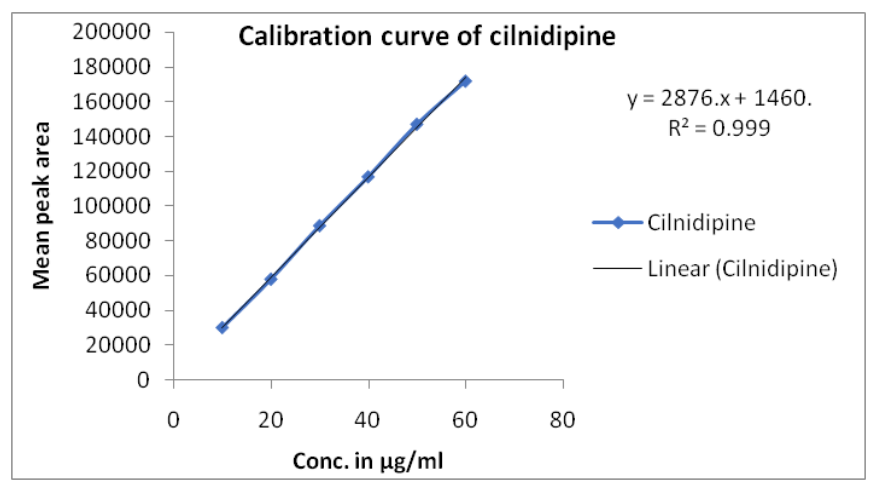

Fig. 3b: Calibration curve of cilnidipine

Table 5: Outcomes of the precision (repeatability) experiment of AZL and CIL (Day 1)

\begin{tabular}{lllllll}
\hline Conc. $(\boldsymbol{\mu g} / \mathbf{m l})$ & \multicolumn{2}{l}{ Avg. peak area $(\mathbf{n = 3 )}$} & SD & \\
\hline AZL & CIL & AZL & CIL & AZL & \%RSD \\
\hline 60 & 15 & 72948.33 & 45636.00 & 1145.27 & 858.31 \\
140 & 35 & 172065.00 & 109402.00 & 2691.16 & 1248.77 \\
220 & 55 & 265062.67 & 168074.67 & 6448.57 & 1.57 & 1.56 \\
\hline
\end{tabular}

$\mathrm{n}=3$ : three repeated injections; Avg. Peak area: Average peak area of three repeated measurements; SD: standard deviation; \%RSD: \%relative standard deviation 
Table 6: Outcomes of intermediate precision of AZL and CIL (Day 2)

\begin{tabular}{lllllll}
\hline Conc. $(\boldsymbol{\mu g} / \mathbf{m l})$ & & Avg. peak area $(\mathbf{n = 3 )}$ & SD & \\
\hline AZL & CIL & AZL & CIL & AZL & CIL & AZL \\
\hline 60 & 15 & 71282.33 & 45080 & 981.92 & 846.39 \\
140 & 35 & 156500.33 & 102620 & 2883.95 & 801.89 \\
220 & 55 & 251937.33 & 160109 & 3995.75 & 1.10 & 1.84 \\
\hline
\end{tabular}

$\mathrm{n}=3$ : three repeated injections; Avg. Peak area: Average peak area of three repeated measurements; SD: standard deviation; \%RSD: \%relative standard deviation

Table 7: Outcomes of intermediate precision of AZL and CIL (Day 3)

\begin{tabular}{|c|c|c|c|c|c|c|c|}
\hline \multicolumn{2}{|c|}{ Conc. $(\mu \mathrm{g} / \mathrm{ml})$} & \multicolumn{2}{|c|}{ Avg. peak area $(n=3)$} & \multicolumn{2}{|l|}{ SD } & \multicolumn{2}{|c|}{ \%RSD } \\
\hline AZL & CIL & AZL & CIL & AZL & CIL & AZL & CIL \\
\hline 60 & 15 & 71095.33 & 44809.00 & 738.76 & 985.22 & 1.04 & 2.20 \\
\hline 140 & 35 & 154319.00 & 99522.33 & 2659.98 & 597.47 & 1.72 & 0.60 \\
\hline 220 & 55 & 249555.00 & 158592.00 & 3078.19 & 842.82 & 1.23 & 0.53 \\
\hline
\end{tabular}

$\mathrm{n}=3$ : three repeated injections; Avg. Peak area: Average peak area of three repeated measurements; SD: standard deviation; \%RSD: \%relative standard deviation

Table 8: Results acquired for robustness experiment with variation in detector wavelength for a mixture of AZL and CIL at 40 and 10 ppm, respectively

\begin{tabular}{|c|c|c|c|c|c|c|c|c|}
\hline \multirow[t]{2}{*}{$\lambda$ in 'nm' } & \multicolumn{2}{|c|}{ Avg. peak area* } & \multicolumn{2}{|c|}{ Avg. measured conc. $(\mu \mathrm{g} / \mathrm{ml})^{\#}$} & \multicolumn{2}{|c|}{$\%$ amount found $(w / w)$} & \multicolumn{2}{|l|}{ Inference } \\
\hline & AZL & CIL & AZL & CIL & AZL & CIL & AZL & CIL \\
\hline 250 & 47217 & 29975 & 41.21 & 9.91 & 103.03 & 99.13 & Complied & Complied \\
\hline 249 & 49762 & 32408 & 39.88 & 10.76 & 99.69 & 107.59 & Complied & Complied \\
\hline 251 & 48258 & 30119 & 38.95 & 9.96 & 97.38 & 99.63 & Complied & Complied \\
\hline
\end{tabular}

*n = 3 Average peak area of three repeated measurements; \#Estimated from regression equation; AZL: Azilsartan Medoxomil; CIL: Cilnidipine

Table 9: Results acquired for robustness experiment with variation organic concentration of the mobile phase for a mixture of AZL and CIL at 40 and 10 ppm, respectively

\begin{tabular}{|c|c|c|c|c|c|c|c|c|}
\hline \multirow{2}{*}{$\begin{array}{l}\text { Organic } \\
\text { conc. '\%' }\end{array}$} & \multicolumn{2}{|c|}{ Avg. peak area* } & \multicolumn{2}{|c|}{ Avg. measured conc. $(\mu \mathrm{g} / \mathrm{ml})^{\#}$} & \multicolumn{2}{|c|}{$\%$ amount found $(w / w)$} & \multicolumn{2}{|l|}{ Inference } \\
\hline & AZL & CIL & AZL & CIL & AZL & CIL & AZL & CIL \\
\hline 80 & 47217 & 29975 & 41.21 & 9.91 & 103.03 & 99.13 & Complied & Complied \\
\hline 78 & 48482 & 30673 & 40.07 & 10.16 & 100.19 & 101.56 & Complied & Complied \\
\hline 82 & 47452 & 30395 & 39.16 & 10.06 & 97.90 & 100.59 & Complied & Complied \\
\hline
\end{tabular}

*n = 3 Average peak area of three repeated measurements; \#Estimated from regression equation; AZL: Azilsartan Medoxomil; CIL: Cilnidipine

Table 10: Results acquired for robustness experiment with variation in mobile phase flow rate in 'ml/min' for a mixture of AZL and CIL at 40 and 10 ppm, respectively

\begin{tabular}{|c|c|c|c|c|c|c|c|c|}
\hline \multirow{2}{*}{$\begin{array}{l}\text { Flow rate } \\
\text { 'ml/min }\end{array}$} & \multicolumn{2}{|c|}{ Avg. peak area* } & \multicolumn{2}{|c|}{ Avg. measured conc. $(\mu \mathrm{g} / \mathrm{ml})^{\#}$} & \multicolumn{2}{|c|}{$\%$ amount found $(w / w)$} & \multicolumn{2}{|l|}{ Inference } \\
\hline & AZL & CIL & AZL & CIL & AZL & CIL & AZL & CIL \\
\hline 1.2 & 47217 & 29975 & 41.21 & 9.91 & 103.03 & 99.13 & Complied & Complied \\
\hline 1.1 & 51562 & 32482 & 42.81 & 10.78 & 107.02 & 107.85 & Complied & Complied \\
\hline 1.3 & 45093 & 28455 & 37.07 & 9.38 & 92.67 & 93.85 & Complied & Complied \\
\hline
\end{tabular}

${ }^{*} \mathrm{n}=3$ Average peak area of three repeated measurements; \# Estimated from regression equation; AZL: Azilsartan Medoxomil; CIL: Cilnidipine

\section{Robustness}

The robustness of the method was studied to establish that the technique remains unaffected by minor but purposeful variations in the method parameters. In this research work, three parameters were varied viz. wavelength, the mobile phase's organic concentration, and the mobile phase's flow rate. The results attained in these three cases were explored in Tables 8, 9, and 10, respectively. The \%amount found of AZL and CIL in this experiment was calculated from the regression equation using the corresponding peak area.

\section{$\%$ Accuracy by \% recovery method}

The \% recovery assessment is a trial to discover two parameters of the method as per ICH guideline Q2R1 viz. accuracy and specificity.
The accuracy of the methods was studied with the planned process by determining the recovered amount of Azilsartan Medoxomil and Cilnidipine by the spike method. A known quantity of standard solutions of drugs (40 and $10 \mu \mathrm{g} / \mathrm{ml}$ of Azilsartan Medoxomil and Cilnidipine as API) were spiked to a sample solution of Azilsartan Medoxomil and Cilnidipine (32, 40, 48 $\mu \mathrm{g} / \mathrm{ml}$ for Azilsartan Medoxomil and 8, 10,12 $\mu \mathrm{g} / \mathrm{ml}$ for Cilnidipine) representing 80, 100 and $120 \%$ levels.

The results observed for \% accuracy are shown in Tables 11 and 12 for AZL and CIL, respectively. To establish the specificity of the method, a blank followed by a sample was injected. It was observed that no interference due to commonly used excipients was seen.

The representative chromatogram observed in the recovery study at the $120 \%$ level is shown in fig. 4 . 


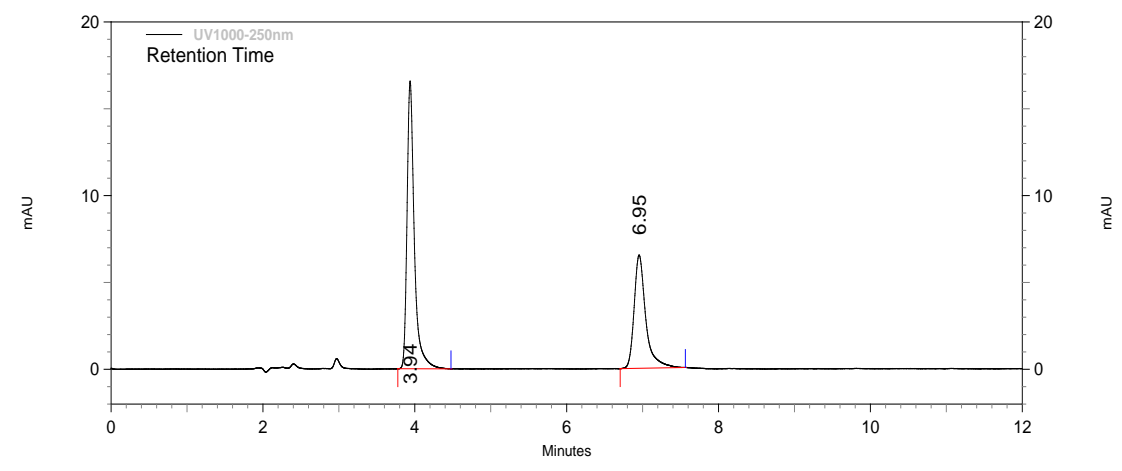

Fig. 4: The chromatogram observed in \% accuracy study at $120 \%$ recovery level

Table 11: Observations noted for \% recovery study of azilsartan medoxomil at three levels

\begin{tabular}{|c|c|c|c|c|c|c|c|}
\hline $\begin{array}{l}\text { \% Recovery } \\
\text { level }\end{array}$ & $\begin{array}{l}\text { Conc. of standard } \\
\text { spiked }(\mu \mathrm{g} / \mathrm{ml})\end{array}$ & $\begin{array}{l}\text { Conc. of the } \\
\text { sample } \\
(\mu \mathrm{g} / \mathrm{ml})\end{array}$ & $\begin{array}{l}\text { Total Avg. peak } \\
\text { area* (test conc.) }\end{array}$ & $\begin{array}{l}\text { Avg. peak Area } \\
\text { of sample conc. }\end{array}$ & $\begin{array}{l}\text { Amount } \\
\text { recovered } \\
(\mu \mathrm{g} / \mathrm{ml})\end{array}$ & $\begin{array}{l}\text { \% Recovery } \\
(w / w)\end{array}$ & Inference \\
\hline 80 & 40 & 32 & 91912 & 44695 & 36.71 & 106.39 & Complied \\
\hline 100 & 40 & 40 & 100695 & 53478 & 44.51 & 101.84 & Complied \\
\hline 120 & 40 & 48 & 110168 & 62951 & 52.91 & 99.87 & Complied \\
\hline
\end{tabular}

${ }^{*} \mathrm{n}=3$ Average peak area of three repeated measurements.

Table 12: Observations noted for \% recovery study of cilnidipine at three levels

\begin{tabular}{|c|c|c|c|c|c|c|c|}
\hline $\begin{array}{l}\text { \% Recovery } \\
\text { Level }\end{array}$ & $\begin{array}{l}\text { Conc. of } \\
\text { standard spiked } \\
(\mu \mathrm{g} / \mathrm{ml})\end{array}$ & $\begin{array}{l}\text { Conc. of the } \\
\text { sample } \\
(\mu \mathrm{g} / \mathrm{ml})\end{array}$ & $\begin{array}{l}\text { Total Avg. peak } \\
\text { area* (test } \\
\text { conc.) }\end{array}$ & $\begin{array}{l}\text { Avg. peak area } \\
\text { of sample conc. }\end{array}$ & $\begin{array}{l}\text { Amount recovered } \\
(\mu \mathrm{g} / \mathrm{ml})\end{array}$ & $\begin{array}{l}\text { \% Recovery } \\
(w / w)\end{array}$ & Inference \\
\hline 80 & 10 & 8 & 54734 & 24759 & 8.10 & 94.51 & Complied \\
\hline 100 & 10 & 10 & 64675 & 34700 & 11.56 & 105.96 & Complied \\
\hline 120 & 10 & 12 & 69149 & 39174 & 13.11 & 99.66 & Complied \\
\hline
\end{tabular}

${ }^{*} \mathrm{n}=3$ Average peak area of three repeated measurements.

\section{LOD and LOQ}

In the proposed method, the LOD and LOQ were estimated by the standard deviation of the responses and the slope. The standard deviation of the responses in turn was calculated from the standard deviation of the y-intercept of the regression line. The standard deviation and the slope were then put in consequent formulae and LOD and LOQ for Azilsartan Medoxomil and Cilnidipine were calculated. The observed outcomes for LOD and LOQ were as tabulated in table 14 .

$$
\begin{aligned}
& \text { LOD (Azilsartan) } \frac{3.3 \times 1936.16}{2336.9} \\
& \text { LOQ (Azilsartan) } \frac{10 \times 1936.16}{2336.9} \\
& \text { LOD (Cilnidipine) } \frac{3.3 \times 1594.11}{4036.2} \\
& \text { LOD (Cilnidipine) } \frac{10 \times 1594.11}{4036.2}
\end{aligned}
$$

Table 13: LOD and LOQ observed for azilsartan medoxomil and cilnidipine

\begin{tabular}{lll}
\hline Standard drug solution & LOD $^{*}(\boldsymbol{\mu g} / \mathbf{m l})$ & LOQ $^{*}(\boldsymbol{\mu g} / \mathbf{m l})$ \\
\hline Azilsartan Medoxomil & 2.73 & 8.29 \\
Cilnidipine & 1.30 & 3.95 \\
\hline
\end{tabular}

*LOD: Detection Limit; LOQ: Quantitation Limit

\section{DISCUSSION}

Extensive literature was studied before the development of the RPHPLC method for Azilsartan Medoxomil and Cilnidipine in bulk as
API. Riddhi J Jani et al. developed a spectrophotometric method to simultaneously estimate Azilsartan Medoxomil Kamedoxomil and Cilnidipine in a synthetic mixture. Beer's law was obeyed in the concentration range of $2-14 \mu \mathrm{g} / \mathrm{ml}$. The process was validated as per ICH guidelines [34]. No other method was observed in the literature for simultaneous estimation of Azilsartan Medoxomil and Cilnidipine. The analytical methods (like HPLC, HPTLC, and UV) for combinations of Cilnidipine or Azilsartan Medoxomil were found to be reported with other drugs. Lakshamana Rao et al. developed a simultaneous method for Chlorthalidone and Cilnidipine. The separation was achieved on C18 (150 x $4.6 \mathrm{~mm}, 5 \mu)$ column using acetonitrile and buffer in the ratio of 35:65 v/v [29]. Leena sawaikar et al. reported stability-indicating the RP-HPLC method for simultaneous determination of Chlorthalidone and Cilnidipine in the dosage form. The gradient elution was used for the separation of the components of the dosage form with different combinations of mobile phases. The regression coefficient was noted as 0.999 for both drugs. The Rt Chlorthalidone was $6.047 \pm 0.2$ and $12.642 \pm 0.2$ for Cilnidipine [35]. Aruna G et al. explores the estimation of Cilnidipine with Nebivolol in human plasma by RP-HPLC. The separation was carried out in isocratic mode on the C18 stationary phase using acetonitrile and buffer as the mobile phase $(45: 55 \% \mathrm{v} / \mathrm{v})$ at a flow rate of $1 \mathrm{ml} / \mathrm{min}$ [31]. Another method for Cilnidipine with Olmesartan medoxomil was developed by Amit Minase et al. The column and detector employed were Hi Q sil C18 column $(250 \times 4.6 \mathrm{~mm}$ i.d. $5 \mu)$ and PDA. The $40 \mathrm{mmol} \mathrm{KH}_{2} \mathrm{PO}_{4}$ buffer was used with methanol as the mobile phase. The Rt observed for Olmesartan medoxomil and Cilnidipine were 2.47 and $6.32 \mathrm{~min}$, respectively [32].

Similarly, few methods with a combination of Azilsartan Medoxomil and other drugs were also found in the literature. Naazneen S et al. reported the RP-HPLC method for simultaneous estimation of Azilsartan Medoxomil medoxomil and Chlorthalidone in the solid dosage form. Hypersil BDS C18 column (100 x $4.6 \mathrm{~mm})$ with Acetonitrile: buffer in the ratio of $10: 90 \% \mathrm{v} / \mathrm{v}$ was employed as 
stationary and the mobile phase, respectively. The Rt noted for Azilsartan Medoxomild and Chlorthalidone were $5.54 \pm 0.5$ and $2.36 \pm 0.1$. The author claimed that the method was suitable and economical [16]. The quality by design (QbD) approach was employed to simultaneously estimate Azilsartan Medoxomil medoxomil and Chlorthalidone using RP-HPLC by Chawla et al. The author used RP-HPLC MINITAB software for optimization of the method parameters. The method was validated as per ICH guidelines and proved to be accurate, precise, and robust [3]. Vekariya Paras et al. have also developed and validated the RP-HPLC method for simultaneous determination of Azilsartan Medoxomil medoxomil and Chlorthalidone using solid-phase extraction technique. The PDA detector at wavelength $254 \mathrm{~nm}$ was employed for the detection of the eluents. The author stated that the method could be employed to study the bioavailability and bioequivalence of Azilsartan Medoxomil Medoxomil Potassium [33].

The presented method's author did not find any RP-HPLC method in literature showcasing the simultaneous estimation of Azilsartan Medoxomil Medoxomil and Cilnidipine in the mixture as bulk. Therefore, this research was planned to develop an RP-HPLC method for simultaneous estimation of Azilsartan Medoxomil Medoxomil and Cilnidipine in the mixture as API and to explore its applicability for quantification of Azilsartan Medoxomil Medoxomil and Cilnidipine in marketed tablet dosage form. The method was developed employing C18 (250 mm×4.6 mm), $5 \mu \mathrm{m}$ id, and Acetonitrile 80: Potassium dihydrogen phosphate buffer (Phosphate buffer) $20 \quad(\mathrm{pH} \quad 3.0) \% \mathrm{v} / \mathrm{v}$ as stationary and mobile phase respectively. The detection was carried out at $250 \mathrm{~nm}$ in isocratic elution mode with a $1.2 \mathrm{ml} / \mathrm{min}$ mobile phase flow rate. The sample size was $10 \mu \mathrm{l}$ with a run time of $12 \mathrm{~min}$ at ambient temperature.

The optimization was done by applying various combinations of the mobile phase and flow rate at various $\mathrm{pH}$ of the aqueous phase (buffer). The mobile phase comprising of Acetonitrile: $\mathrm{KH}_{2} \mathrm{PO}_{4}$ buffer at $\mathrm{pH} 3.0$ in the ratio of $80: 20 \% \mathrm{v} / \mathrm{v}$ was seen most promising for separation of the AZL and CIL. The retention time (Rt) of 3.99 \pm 0.03 and 7.12 \pm 0.06 was noted for AZL and CIL, respectively, with the aforesaid mobile phase combination. The system suitability test (SST) was performed to ensure the appropriate working of the system. The \%RSD noted for the average peak area in SST for AZL and CIL were 1.32 and 1.90, respectively. The results seen were within acceptance criteria as per ICH Q2R1 guidelines. The series of standard concentrations of AZL and CIL showed excellent linear relation with corresponding average peak area with a regression coefficient of 0.9996 and 0.9993 , respectively. The equation of line $1127.1 x+3313.9$ and $2876.4 x+1460.2$, slope 1127.1 and 2876.4 were observed for AZL and CIL correspondingly. The linearity was seen in the range of $40-240 \mu \mathrm{g} / \mathrm{ml}$ for AZL and $10-60 \mu \mathrm{g} / \mathrm{ml}$ for CIL. The precision of the method was studied by repeatability and intermediate precision. The outcomes of the repeatability showed $\%$ RSD values in the acceptance criteria for CIL. For AZL the repeatability at one standard viz. $220 \mu \mathrm{g} / \mathrm{ml}$ was observed 2.43 which were found to be slightly deviated from the acceptance criteria as per ICH guideline. The remaining two standard concentrations of AZL were seen within acceptable limits as per ICH guideline Q2R1. The intermediate precision for AZL as well as CIL was observed within acceptance criteria (\%RSD less than 2, table 6 and 7) at all three standard concentration levels except for CIL at $15 \mu \mathrm{g} / \mathrm{ml}$ on Day 2 (table 6). Therefore, it was seen that the presented method was precise.

The robustness of the method was studied by deliberate variations in the method parameters viz. wavelength in ' $\mathrm{nm}$ ', organic conc. of the mobile phase in ' $\% \mathrm{v} / \mathrm{v}$ ', and flow rate. The respective average peak area of both the drugs was kept in the regression equation to estimate the average measured conc. of AZL and CIL. The \%assay was also calculated from the average measured concentration and standard concentration. As shown in table 8 the \%assay was found to be $97.38-103.03 \% \mathrm{w} / \mathrm{w}$ and $99.13-107.59 \% \mathrm{w} / \mathrm{w}$ for AZL and CIL, respectively. Similarly for organic concentration variation it was 97.90-103.03\% w/w and 99.13-101.56\% w/w (table 9). Finally, variation in flow rate the \%assay was seen as 92.67 to $103.03 \% \mathrm{w} / \mathrm{w}$ and $93.85-107.85 \% \mathrm{w} / \mathrm{w}$ (table 10 ) for AZIL and CIL respectively. The results were seen well within the boundaries prescribed for AZL and CIL. Therefore, it was observed that the presented method was robust.

The accuracy of the method was studied by estimation of \%recovery using marketed tablet dosage form. The results observed were as tabulated in table 11 for AZL and table 12 for CIL. From the outcomes of this experiment, the \%accuracy for AZL was noticed in the range of $99.87-106.39 \% \mathrm{w} / \mathrm{w}$ (table 11). Similarly, the \%accuracy for CIL was noted in the range of $94.51-105.96 \% \mathrm{w} / \mathrm{w}$. The outcomes were within acceptance criteria for AZL and CIL as per their respective compendial standards. LOD and LOQ of the AZL were 2.73 and $8.29 \mu \mathrm{g} / \mathrm{ml}$, respectively. Furthermore, LOD and LOQ for Cilnidipine were 1.30 and $3.95 \mu \mathrm{g} / \mathrm{ml}$, respectively (table 12 ). The specificity of the method was studied by injecting blank solution followed by injection of the sample solution from the tablet dosage form. The blank conc. showed no peak and the sample showed two peaks at the position of AZL and CIL, respectively. Therefore, this has suggested no interference in detecting AZL and CIL by commonly used excipients used in manufacturing the marketed tablet dosage form. This proved specificity (selectivity) of the method for estimation of AZL and CIL.

\section{CONCLUSION}

RP-HPLC method was successfully developed to simultaneously estimate Azilsartan Medoxomil and Cilinidipine in the mixture as API. Also, the method was productively tested for its applicability for convention analysis of Azilsartan Medoxomil and Cilnidipine in combined marketed tablet dosage form with results in compliance with the standards. The method was also proved unambiguous for estimating Azilsartan Medoxomil and Cilnidipine in the sample matrix of the tablet dosage form (marketed formulation). Hence, the presented method can be successfully employed for a custom analysis of Azilsartan Medoxomil and Cilinidipine in marketed tablet dosage forms.

\section{ACKNOWLEDGEMENT}

The authors are thankful to the management of Y B Chavan College of Pharmacy, Aurangabad MS, India for providing the required facilities and support in carrying out this work.

\section{FUNDING}

Any financial institution did not fund this research project.

\section{AUTHORS CONTRIBUTIONS}

Ms. Swati Andhale has generated the research plan, prepared and revised the manuscript and Prof. Dr. A. G. Nikalje has provided guidance and supervision to carry out this study. Also, Prof. Dr. A. G. Nikalje has supported data analysis.

\section{CONFLICTS OF INTERESTS}

All authors have none to declare.

\section{REFERENCES}

1. Sanjay Kumar D, Harish Kumar DR. Importance of RP-HPLC in analytical method development: a review. IJPSR. 2012;3(12):4626-33.

2. Ravi Sankar P, Sai Snehalatha K, Shaik TF, Srinivasa Babu P. Applications of HPLC in pharmaceutical analysis. Int J Pharm Sci Rev Res 2019;59(1):117-24.

3. Sohni SK, Kumar R, Akhtar M, Ranjan C, Chawla G. Development and validation of RP-HPLC method for simultaneous estimation of azilsartan medoximil and chlorthalidone in bulk form and formulation using quality by design. Int J Pharm Sci Rev Res. 2016;8(2):266-72.

4. Baker WL, White WB. Azilsartan medoxomil: a new angiotensin II receptor antagonist for the treatment of hypertension. Ann Pharmacother. 2011;45(12):1506-15. doi: 10.1345/aph.1Q468, PMID 22116996.

5. White WB, Weber MA, Sica D, Bakris GL, Perez A, Cao C, Kupfer S. Effects of the angiotensin-receptor blocker azilsartan medoxomil versus olmesartan and valsartan on ambulatory and clinic blood pressure in patients with stages 1 and 2 hypertension. Hypertension. 2011;57(3):413-20. doi: 10.1161 /hypertensionaha.110.163402, PMID 21282560. 
6. Perry CM. Azilsartan medoxomil: a review of its use in hypertension. Clin Drug Investig. 2012;32(9):621-39. doi: 10.2165/11209600-000000000-00000, PMID 22877322.

7. Datar PA, Aher SB, Washimkar MH, Auti PB. 2DQSAR of novel 1, 4-dihydropyridine derivative blocking n-type-calcium channels. J Chem Pharm Res. 2012;4:1117-22.

8. Rupareliya RH, Joshi HS. Stability indicating simultaneous validation of telmisartan and cilnidipine with forced degradation behavior study by RP-HPLC in tablet dosage form; 2013.

9. Iyer RP, Lindsey ML, Chilton RJ. A two-for-one bargain: using cilnidipine to treat hypertension and its comorbidities. J Clin Hypertens (Greenwich). 2013;15(7):455-7. doi: 10.1111/jch.12112. PMID 23815532.

10. Takahara A, Nakamura Y, Wagatsuma H, Aritomi S, Nakayama A, Satoh Y, Akie Y, Sugiyama A. Long-term blockade of L/N-type $\mathrm{Ca}(2+)$ channels by cilnidipine ameliorates repolarization abnormality of the canine hypertrophied heart. Br J Pharmacol. 2009;158(5):1366-74. doi: 10.1111/j.14765381.2009.00407.x, PMID 19785655.

11. Fujii S, Kameyama K, Hosono M, Hayashi Y, Kitamura K. Effect of cilnidipine, a novel dihydropyridine $\mathrm{Ca}^{++}$-channel antagonist, on $\mathrm{N}$-type $\mathrm{Ca}^{++}$channel in rat dorsal root ganglion neurons. J Pharmacol Exp Ther. 1997;280(3):1184-91. PMID 9067302.

12. Hosono M, Fujii S, Hiruma T, Watanabe K, Hayashi Y, Ohnishi H, Takata $\mathrm{Y}$, Kato $\mathrm{H}$. Inhibitory effect of cilnidipine on vascular sympathetic neurotransmission and subsequent vasoconstriction in spontaneously hypertensive rats. Japan J Pharmacol. 1995;69(2):127-34. doi: 10.1254/jjp.69.127, PMID 8569049.

13. Shrinivasan R, Kamal Chandra J, Kumar R, Dushyant Kumar N. Stability indicating RP-HPLC method for determination of azilsartan medoxomil in bulk and its dosage form. IJPAR. 2014;3(4):445-52.

14. Masthanamma SK, Jahnavi P. Stability indicating RP-HPLC method for determination of azilsartan medoxomil in pharmaceutical dosage form. Res J Pharm Technol. 2014;7(2):168-72.

15. Sreenivasulu J, Venkata Ramana P, Sampath Kumar Reddy G, Nagaraju ChV, Thirumalai Rajan S, Eswaraiah S. A rapid novel HPLC method for estimation of eight related compounds in azilsartan kamedoxomil and identification of degradation compounds by using LC-MS. J Chromatogr Sci. 2015;53(9):1463-74. doi: 10.1093/chromsci/bmv039, PMID 25925084.

16. Naazneen S, Sridevi A. Stability-indicating RP-HPLC method for the simultaneous estimation of azilsartan medoxomil and chlorthalidone in solid dosage forms. Int J Pharm Pharm Sci. 2014;6(6):236-43.

17. Aher SS, Saudagar RB, Kothari H. Development and validation of RP-HPLC method for simultaneous estimation of azilsartan medoxomil and chlorthalidone in bulk and tablet dosage form. Int J Curr Pharm Sci. 2018;10(6):21-4. doi: 10.22159/ijcpr.2018v10i6.30967.

18. Pawar VT, Pawar SV, More HN, Kulkarni AS, Gaikwad DT. RPHPLC method for simultaneous estimation of cilnidipine and chlorthalidone. Rese J Pharm Technol. 2017;10(11):3990-6. doi: 10.5958/0974-360X.2017.00724.7.

19. Satyavati D, Kumar AG, Latha MB, Madhukar A. Validated RPHPLC method for simultaneous estimation of chlorthalidone and cilnidipine in API and tablet dosage form. J Sci Res Pharm. 2018;7(11):124-9.
20. Sunitha N, Marihal SC, Sravanthi SJ, Venu A, Narasimha Rao BV, Appa Rao B. Method development and validation of RP-HPLC method for the simultaneous estimation of olmesartan and cilnidipine in bulk and formulations. IJPRAS. 2015;4(3):127-35.

21. Araujo P. Key aspects of analytical method validation and linearity evaluation. J Chromatogr B Anal Technol Biomed Life Sci. 2009;877(23):2224-34. doi: 10.1016/j.jchromb.2008.09.030, PMID 18929516.

22. Lakshmi B, Reddy TV. A novel RP-HPLC method for the quantification of linagliptin in formulations. J Mol. 2012;2:155.

23. Joshi R, Sharma R. Development and validation of RP-HPLC method for simultaneous estimation of three-component tablet formulation containing acetaminophen, chlorzoxazone, and aceclofenac. Anal Lett. 2008;41(18):3297-308. doi: 10.1080/00032710802515086.

24. Vander Heyden Y, Nijhuis A, Smeyers Verbeke J, Vandeginste BG, Massart DL. Guidance for robustness/ruggedness tests in method validation. J Pharm Biomed Anal. 2001;24(5-6):723-53. doi: 10.1016/s0731-7085(00)00529-x, PMID 11248467.

25. Ferreira SLC, Caires AO, Borges TdS, Lima AMDS, Silva LOB, dos Santos WNL. Robustness evaluation in analytical methods optimized using experimental designs. Microchem J. 2017;131:163-9. doi: 10.1016/j.microc.2016.12.004.

26. Patel SN, Hinge MA, Bhanushali VM. Development and validation of a UV spectrophotometric method for simultaneous determination of cilnidipine and chlorthalidone. J Pharm Res. 2015;9:41-5.

27. Uhrovcik J. Strategy for determination of LOD and LOQ values-some basic aspects. Talanta. 2014;119:178-80. doi: 10.1016/j.talanta.2013.10.061, PMID 24401401.

28. Jain JJ, Patel SA. Development and validation of spectrophotometric method for simultaneous estimation of azilsartan kamedoxomil and cilnidipine in the synthetic mixture. World J Pharm Res. 2018;7(8):948-58.

29. Rao AL, Eswarudu MM, Vijay K. Bioanalytical method development and validation for simultaneous determination of chlorthalidone and cilnidipine drugs in human plasma by RPHPLC. Int J Res Pharm Chem. 2019;9(1):33-44.

30. Sawaikar L, Kapupara P. Development and validation of a stability indicating RP-HPLC method for the estimation of chlorthalidone and cilnidipine in combined pharmaceutical dosage form. Res J Pharm Technol. 2020;13(5):2376-80. doi: 10.5958/0974-360X.2020.00427.8.

31. Aruna G, Bharathi K. Prasad, development and validation of bioanalytical HPLC method for simultaneous estimation of cilnidipine and nebivolol in human plasma. Int J Pharm Pharm Sci. 2017;9(10):253-9.

32. Minase AS, Dole MN, Sawant SD. Development and validation of an analytical method for simultaneous estimation of cilnidipine and olmesartan medoxomil in bulk and tablet dosage form by RP-HPLC. Int J Pharm Pharm Sci. 2014;6(7):508-11.

33. Vekariya PP, Joshi HS. Development and validation of RP-HPLC method for azilsartan medoxomil potassium quantitation in human plasma by solid phase extraction procedure. ISRN Spectrosc. 2013;2013:1-6. doi: 10.1155/2013/572170.

34. Jani RJ, Patel SA. Spectrophotometric method for simultaneous estimation of azilsartan kamedoxomil and cilnidipine in the synthetic mixture. Int J Pharm Pharm Sci. 2018;3(2):86-90. 